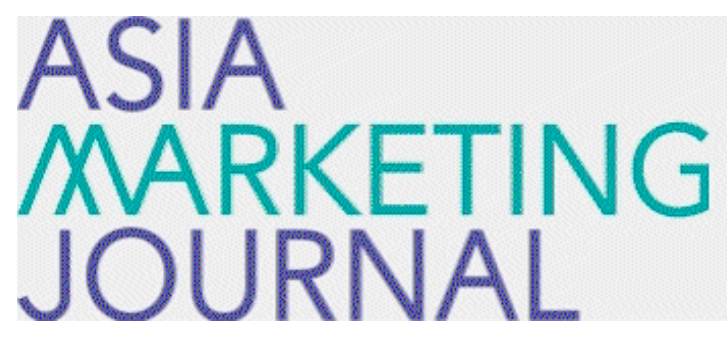

ASIA MARKETING JOURNAL

Volume 7 | Issue 3

Article 7

10-27-2005

\title{
대한민국 데이터베이스 마케팅 인프라 구축을 위한 KT 소디스 사업 의 마케팅 전략
}

Byung Do Kim

Seong Tae Hong

Jong Chil Shin

Kang

Follow this and additional works at: https://amj.kma.re.kr/journal

Part of the Marketing Commons

\section{Recommended Citation}

Kim, Byung Do; Hong, Seong Tae; Shin, Jong Chil; and Kang (2005) "대한민 국 데이터베이스 마케팅 인프라 구 축을 위한 KT 소디스 사업의 마케팅 전략," Asia Marketing Journal: Vol. 7 : Iss. 3 , Article 7.

Available at: https://doi.org/10.53728/2765-6500.1154

This Article is brought to you for free and open access by Asia Marketing Journal. It has been accepted for inclusion in Asia Marketing Journal by an authorized editor of Asia Marketing Journal. 


\title{
대한민국 데이터베이스 마케팅 인프라 구축을 위한 $\mathrm{KT}$ 소디스 사업의 마케팅 전략
}

\section{The First Step toward Database Marketing Industry in Korea; KT SODiS Case}

\author{
김 병 도( $\mathrm{Kim}, \mathrm{Byung}-\mathrm{Do})^{*}$ \\ 홍 성 태(Hong, Seongtae)** \\ 신 종 칠(Shin, Jong Chil)*** \\ 강 명 수(Kang, Myung Soo)*
}

$\mathrm{KT}$ 는 고객정보를 중심으로 새로운 사업을 개발하고 이를 출범시킴으로써 불모지나 다름없는 국내 데이터베이스 마케팅 산업의 초석을 다지기 위해 노력하였다. 여러 어려움을 극복하고 다양한 마케팅 활동을 통해 200 만명의 고객정보를 확보하고 이러한 정보를 이용하고자 하는 기업들의 수요를 찾아 냄으로써 국내 시장에 데이터베이스 마케팅 산업의 잠재력이 충분히 존재한다는 것을 보여주었다. 본 사례는 국내 데이터베이스 산업의 활성화를 위해 인프라를 구축하고자 한 $\mathrm{KT}$ 소디스 사업의 의미와 마케팅전략을 살퍼보고 향후에 해결해야 할 주요 과제들을 제시하고 있다.

핵심개념: $\mathrm{KT}$ 소디스, 데이터베이스마케팅, 고객정보 보호, 마케팀전략

\section{I. 서 론}

최근 연일 개인정보 유출과 관련된 사건들이 뉴스 보도를 장식하고 있다. TV. 신문광고 등 을 활용한 매스마케팅의 한계에 봉착한 기업

\footnotetext{
* 서울대학교 경영대학 교수(bxk@snu.ac.kr)

** 상명대학교 국제통상학과 부교수(sthong@smu.ac.kr)

*** 건국대학교 부동산학과 조교수(jcshin@konkuk.ac.kr)

**** 한성대학교 무역학과 조교수(mskang@hansung.ac.kr)
}

들은 좀 더 싼 가격으로 더 효율적인 마케팅 을 하고자 고객의 정보를 활용한 일대일 마케 팅(one-to-one marketing) 혹은 타겟 마케팅 (target marketing)을 그 해법이라고 여기고 있 다. 그러나 많은 기업들이 데이터베이스 마케팅 을 하고자 해도, 합법적인 가능한 방법이 없는 
〈그림 1-1〉 소디스 사업 추진 과정
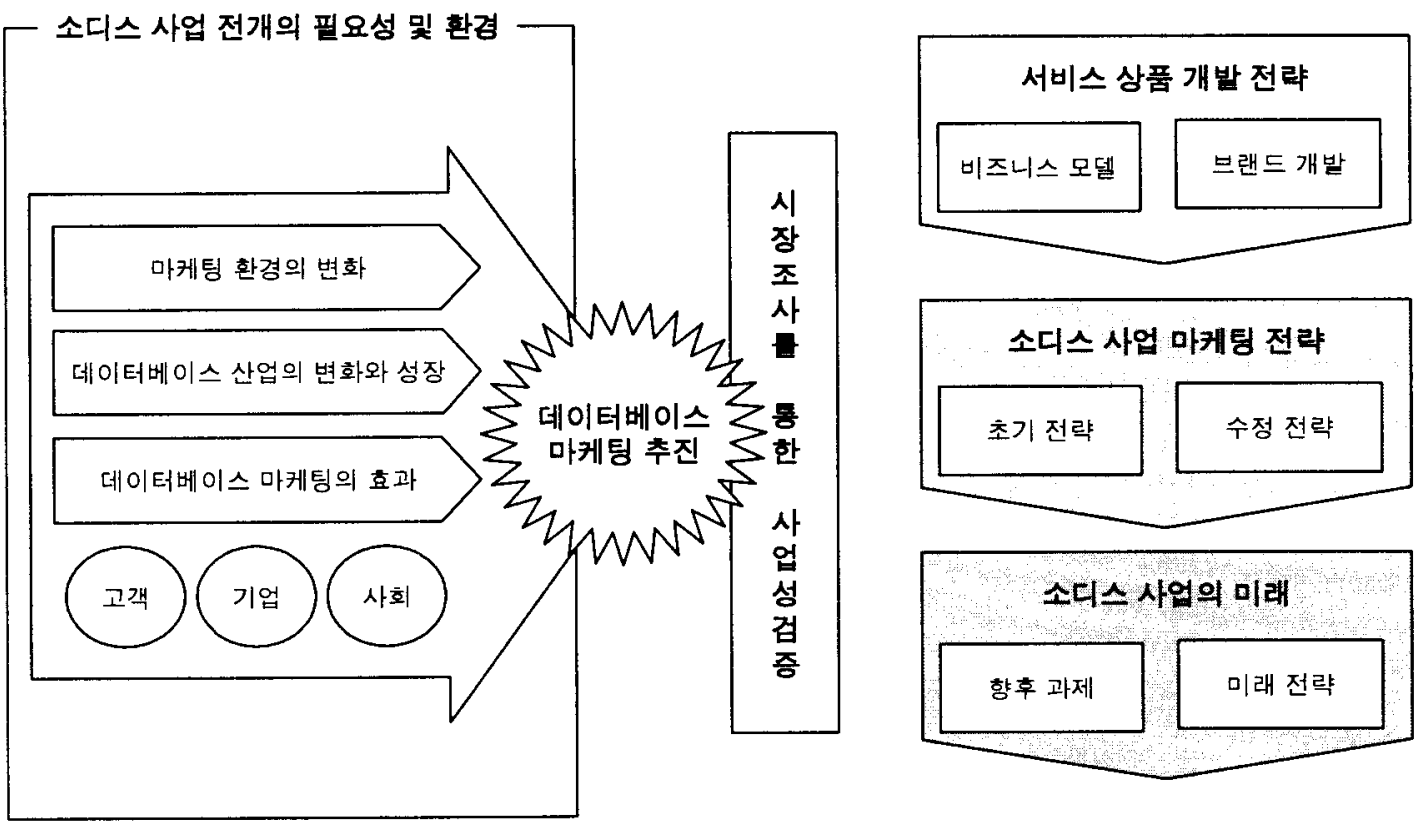

것이 현실이다. 원하는 고객에게 마케팅 활동을 하기 위해서는 고객 정보가 필요한데, 개인의 프라이버시 보호라는 명목으로 현재 국내에서 고객정보의 유통은 엄격한 기준으로 규제되고 있기 때문에 실질적으로 합법적인 고객정보의 획득은 불가능한 것이다.

이러한 상황에서 기업이 데이터베이스 마케팅 을 할 수 있는 방법은 불법적인 경로를 통해 개인정보를 획득하는 방법뿐이다. 현실적 마케 팅 환경이 이러하다 보니, 지금까지 국내 데이 터베이스 마케팅 시장은 개인정보를 제대로 활 용하지도 못하고 보호하지도 못하는 불법적인 유통만 난무하는 상황에 처해 있다고 할 수 있 다. 이에 따라 사회적으로는 개인정보의 불법유 출 사고가 점점 많아지고, 개인정보유출이 사회 적 이슈로 대두되게 되었다.

이에 KT는 데이터베이스 마케팅 산업의 혼
란한 시장상황에 적절한 기준을 세워 새로운 산업분야를 개척하고자 $\mathrm{KT}$ 소디스라는 새로운 사업을 출시하였다. $\mathrm{KT}$ 소디스 사업은 개인정보 의 유통을 더 이상 불법적인 것으로만 치부할 것이 아니라, 합리적 기준 하에서 개인정보의 보호와 활용을 동시에 이뤄낼 수 있다는 것을 보여주고자 하는 최초의 시도였다고 할 수 있다. 본 사례를 통해서 데이터베이스 마케팅 산업 의 기반이 되는 고객정보의 유통을 사업화하기 위해 고심했던 $\mathrm{KT}$ 의 고민과 정보제공에 대한 고객동의를 얻기 위해 여러 시행착오를 거치면 서 가장 효과적인 마케팅 방법을 찾아가는 과 정을 살펴보고자 한다. 또한 우리나라 기업들이 효과적으로 데이터베이스 마케팅을 할 수 있기 위해 극복해야 할 여러 장애요인과 데이터베이 스 마캐팅 산업을 활성화하기 위한 향후 과제 들을 아울러 고찰하고자 한다. 


\section{II. 소디스 사업 전개의 필요성 및 환경}

KT에서 소디스 사업을 추진하고 있는 소디 스 사업관련 직원들은 2005 년 2월 일 축제분위 기에 젖었다. 마침내 200 만 명의 고객으로부터 자신의 정보제공에 대한 동의를 얻었던 것이다. 200 만 명의 고객정보를 가짐으로써 본격적인 정보유통사업이 가능하다는 점도 있었지만 그 동안의 어렵고 힘든 과정과 고생이 보상을 받 았다는 느낌에 더욱 감동이 크게 느껴졌다. 주 변 사람들이 왜 사서 고생을 하느냐고 말을 했 을 때마다 나름대로 이 사업은 돈이 목적이 아 니라 우리나라를 위해서 반드시 필요한 사업이 라는 사명감을 가지고 사업을 추진해 왔다. 이 들은 200 만 고객을 확보한 시점에서 그 동안의 지나온 과정들과 앞으로 해야 할 일들을 정리 해보았다.

\section{1 마케팅환경의 변화}

전통적 방식의 대량 마케팅에서 탈피하여, 고 객의 니즈에 맞춘 새로운 마케팅 방식으로의 전환이 필요하다는 것에 대해서 많은 사람들이 공감하고 있다. 이러한 마케팅을 시행하기 위해 서 고객정보는 반드시 필요한 필수불가결한 기 초가 되는 것이다. 데이터베이스 마케팅(database marketing), 일대일 마케팅(one-to-one marketing), 고객관계관리(customer relationship marketing) 등 다양한 이름으로 불려지지만 공통된 내용은 개별 고객의 특성과 상황을 고려하고 고객이 원하는 다양한 욕구를 충족시켜, 고객이 당면한
문제를 해결해주는 마케팅 활동이다. 이러한 마 케팅활동을 성공적으로 수행하기 위해서는 얼 마나 정확하고 풍부한 고객의 정보를 확보하고 있는가가 관건이 된다. 고객이 원하는 것이나 고객이 당면한 문제를 해결하기 위해서 기업은 고객의 정보를 수집, 관리, 분석할 필요가 있다. 이에 따라 무형의 정보자원이 이제 기업의 경 쟁력을 좌우하게 됨에 따라 기업들 간의 경쟁 은 정보경쟁이라고 해도 과언이 아닐 것이다.

\section{2 국내외 데이터베이스 마케팅 산업현황}

데이터베이스 마케팅에 대한 관심이 증가함에 따라 데이터베이스 마케팅 산업은 급속하게 성 장해 왔다. 1999년 A.T Kearney가 조사한 자 료에 따르면 미국의 데이터베이스 마케팅 관련 산업의 시장규모는 약 5,520 억 달러(약 662 조 원)였고, $\mathrm{DMA}$ 의 자료에 따르면 전세계 다이렉 트마케팅(데이터베이스 마케팅의 일부 영역)의 시장규모는 2002년에 4,115억 달러(약 494조원) 를 기록했다. 또 연평균 $8 \%$ 이상의 고속 성장을 거듭하여, 2007년에는 5,745억 달러(약 689억원) 로 성장할 것으로 예측되었다. 미국의 대표적인 데이터베이스 유통 및 관리 회사인 $\mathrm{AXCIOM}$ 사의 1999년 한해 매출액만 보더라도 약 1 조 1000 억원에 달한다. 미국에 비하여 상대적으로 산업에 대한 규제가 강한 유럽의 경우에도 2002 년 기준으로 영국은 약 22 조원, 독일의 경 우에는 약 34 조원, 프랑스는 약 20 조원 정도의 다이렉트 마케팅 시장이 형성되어 있다. 이렇게 데이터베이스 마케팅 분야가 빠르게 성장한 것 은 마케팅 패러다임의 변화로 기업들이 대량 마케팅이 아니라 고객과 상호작용할 수 있는 
마케팅에 보다 많은 자원을 투자할 것이기 때 문이다.

우리나라의 경우 데이터베이스 마케팅 관련 산업의 시장규모를 추정한 기존 자료가 없기 때문에, 해외의 경우를 바탕으로 잠재력을 추론 할 수밖에 없다. 미국의 국내총생산(GDP) 대 비 데이터베이스 마케팅 관련 산업 시장규모의 비율을 이용해 우리나라의 잠재시장규모를 추 정해 본다면 약 242억 달러(29조원)에 이른다. 또한 데이터베이스 마케팅 관련 산업은 매우 노동집약적인 산업이어서, 우리나라에서 관련 산업이 활성화되어 미국 수준으로 발달한다면 우리나라 전체 경제활동 인구 2,356만 명의 $10 \%$, 즉 약 230 만 명의 고용효과가 발생할 것 으로 보인다. 그러나. 데이터베이스 마케팅 산 업이 발전하기 위하여 가장 기본이 되는 것이 바로 고객정보인데, 우리나라에서 고객정보의 산업적 활용은 그 통로가 거의 막혀있어 불가 능한 상황이라고 할 수 있다. 이는 물론 개인정 보의 활용에 따른 불필요한 정보유출을 우려하 는 데 가장 큰 이유가 있기는 하지만 그로 인 하여 개인정보 활용을 마케팅 활동에 합법적으 로 사용하여 성과를 달성할 수 있는 긍정적인 측면도 포기하고 있는 것이다.

고객정보의 활용은 과거 모든 대중을 대상으 로 한 무차별적인 마케팅을 줄이는 효과를 만 들어낸다. 이에 따라 불필요한 우편물이나 광고 물, 광고전화, 광고메일 등을 줄일 수 있다. 서 울대 경영연구소의 2004년 연구결과에 따르면, 불필요한 우편물로 인한 사회적 비용이 연간 5,500 억원에 달하는 것으로 나타났으며 여기에 불필요한 광고물, 광고전화, 스팸메일까지 포함 시키면 그 비용은 가히 천문학적이라고 할 수
있을 것이다. 기업이 고객정보를 활용해 필요한 경우에만 마케팅활동을 한다고 생각하면 그와 같 은 사회적 비용은 크게 줄어들 수 있을 것이다.

통계청 자료에 따르면 연간 우리나라 전체 인 구의 $20 \%$ 이상이 이사 등으로 주소를 변경하 고 있다고 한다. 그러나 자신에게 우편물을 발 송하던 기업이나 단체에 주소이전 사실을 알리 지 않아 반송 및 재발송을 위해 엄청난 인력과 자원이 낭비되고 있다. 우편물을 발송하는 기업 도 우편물 반송 및 재발송으로 입는 손실액이 연간 수천억 원에 이른다.

미국은 이 문제를 독특한 방법으로 해결하고 있다. 미국에도 반송 우편물이 없는 것은 아니 지만 국내에 비해 그 비율이 현저히 낮다. 많은 미국인은 이사를 가면서 우체국에 이사 갈 집 의 주소를 남겨놓는다. 우체국은 주소 이전을 신고한 고객에 대해 1 년 동안 무료로 옛 주소 지로 발송된 우편물을 새 주소지로 배달해 준 다. 이 과정을 통해 미 체신부는 전국 방방곡곡 의 우체국에서 수집된 주소지 변경 고객 명단 을 데이터베이스로 구축해 기업에 주소변경 서 비스를 제공하고 있다. 이러한 미국의 주소정보 갱신 시스템은 사회 구성원 모두에게 이익을 주고 있다. 우체국은 주소갱신 서비스를 제공함 으로써 추가 수입이 발생하고 반송우편 수가 현저히 줄어 집배원 업무 부담을 줄일 수 있어 좋다. 주소갱신 서비스를 제공받는 기업은 저렴 한 비용으로 고객 주소를 갱신해 발송비용을 절약하고, 마케팅활동의 효율성을 증진할 수 있 어 좋다. 국민들도 이사로 인한 분실 우편물을 최소화할 수 있어 이득을 얻는다. 물론 주소변 경 서비스를 원치 않는 미국인은 자신의 이름 을 주소지 변경 고객명단에서 뺄 수 있다. 개별 
고객은 이에 더하여 기업이 정확한 고객 정보 를 활용하여 마케팅 활동을 전개함으로써 자신 에게 적합한 맞춤형 서비스를 제공받을 수 있 다. 개인적인 취미생활을 위해 정보를 얻고자 해도 어디서 좋은 정보를 구해야 할지 모를 때 가 흔히 있는데 기업이 개인 취미를 미리 알고 고객이 필요로 하는 정보를 제공한다면 개인은 그와 같은 정보를 구하기 위한 비용을 크게 줄 일 수 있을 것이다. 또한 고객정보를 잘 활용함 으로써 고객만족 이상의 고객감동을 실현할 수 도 있을 것이다.

우리나라의 경우 고객정보 보호를 위해 고객 정보를 활용하는 사업에 대하여 엄격한 법적 규제를 가하고 있기 때문에, 국내 기업의 데이 터베이스 마케팅 산업으로의 진출은 매우 부실 하다. 고객정보를 부작용 없이 효과적으로 활용 하게 하여 산업을 활성화시킬 수 있는 통로를 마련하는 것이 국가나 기업의 경제적 측면을 고려할 때 우선시되어야 한다. 합리적인 기준 하에서 보호와 활용을 동시에 이뤄낼 수 있는 인프라를 구축하는 것이 절실한 시점이라는 것 을 대부분의 기업이 통감하고 있다.

\section{$2.3 \mathrm{KT}$ 의 데이터베이스 마케팅 추진}

국내 데이터베이스 마케팅 산업의 출발이라고 볼 수 있는 소디스는 그 사업의 주체가 $\mathrm{KT}$ 라 는 점에서 더 큰 의미가 있다. 물론 데이터베이 스 마케팅을 근간으로 하는 사업은 고객의 정 보를 보유하고 있는 기업은 누구라도 가능하다. 그러나 $\mathrm{KT}$ 의 경우 국내 어느 기업보다 방대한 양의 개인고객 정보를 보유하고 있으며. 전화번 호와 주소는 고객이 이사할 때마다 업데이트하
므로 가장 최신의 상태로 유지되는 가치 있는 정보라 할 수 있다. 실제로 이동통신 기업들도 1,000 만 명 이상의 고객을 보유하고 있어 고객 정보의 수는 방대하지만. 이동통신의 경우 고객 의 주소정보는 실시간으로 업데이트 되지 않기 때문에 이동통신사가 고객에게 접촉할 수 있는 수단은 오직 휴대폰정보 뿐이다.

$\mathrm{KT}$ 고객 정보는 어느 한 개인이 아닌 가구 의 정보라고 볼 수 있다. 주로 유선전화의 계약 자는 집안의 가장인 경우가 대부분으로 계약자 의 성별 및 나이 정보를 통하여 가구정보를 추 정해 낼 수 있다. 평균 결혼연령, 평균 자녀 수 및 자녀의 나이 등 표준자료에 따라 추정하면, 실제 계약자의 가구 환경과 상당비율 유사하다 는 결론을 얻을 수 있다. 다양한 고객분석 솔루 션을 활용하여 $\mathrm{KT}$ 에서는 각 고객의 가구정보 를 추정할 수 있기 때문에, 마케팅 측면에서 본 다면 상당히 가치 있는 수준의 정보라 할 수 있다. 결혼 초기의 젊은 부부로 어린 아기가 있 을 것으로 추정되는 부부에게는 아기용품에 대 한 마케팅을, 중고생 자녀를 두었을 것 같은 가 정에는 자녀교육을 위한 상품의 마케팅을 위한 타겟고객으로 분류할 수 있을 것이다.

소디스 사업이 성공적으로 추진된다면 다양한 사적 편익과 공적 편익을 창출할 수 있다. 사회 적으로 볼 때 고객정보의 적정한 활용을 촉진 함으로써 매년 7천억 원 이상에 달하는 우편물 오발송 비용을 절감하는 사회적 공익성을 기대 할 수 있다. 또한, 정확한 주소로의 우편물 배 달로 인하여 개인의 프라이버시가 적절히 보호 되는 기대효과를 생각해 볼 수 있다. 지금까지 는 개인이 이사를 하면 주소. 전화번호 등의 정 보를 개인이 직접 기업에 변경신청 했어야만 
하고, 실수로 잊어버리고 변경하지 못하는 경우 예전 주소로 계속해서 본인의 우편물이 발송되 어 개인정보 유출의 위험까지 우려되었다. 소디 스의 고객정보 갱신 서비스는 기업이 보유하고 있는 자사의 고객정보를 소디스를 통해 쉽게 갱신할 수 있도록 한다. 또, 갱신이 아니라 자 사의 고객정보가 맞는지 틀리는지 여부를 $\mathrm{KT}$ 소디스 서비스를 통해 확인만 해도 기업은 고 객의 잘못된 주소로는 우편물을 발송하지 않을 수 있을 것이다. 이 서비스를 통해 정보가 정확 치 않은 고객을 마케팅 대상에서 제외하기만 하더라도 엄청난 마케팅비용이 절감될 것이다.

소디스의 표적고객선정 서비스를 통해 무차별 적인 스팸성 메일을 줄이고, 실제로 고객에게 필요한 마케팅 정보만을 전달할 수 있는 환경 을 조성할 수 있다. 그리하여 보다 합리적인 마
케팅 방법을 활성화시킴으로써 기업의 마케팅 이 더 이상 귀챃고 필요 없는 것이 아니라 고 객으로부터 환영받을 수 있는 활동을 시도할 수 있을 것이다. 그러나. 표적고객선정 서비스 를 이용한다고 해도 다른 기업에 목표 고객의 정보리스트를 제공해야 하기 때문에 개인정보 유출의 위험성이 존재하게 된다. 개인정보의 유 출위험을 최소화하면서 타겟 마케팅을 수행할 수 있는 또 하나의 방법은 KT가 제 3 자 기업의 마케팅을 대행하는 것이다. 소디스의 마케팅 대 행서비스는 고객의 정보를 다른 기업에 제공하 지 않으면서, 마케팅을 원하는 기업의 광고내용 은 고객에게 전달될 수 있도록 하는 서비스이다. 소디스는 개인정보의 유출에 대한 논란을 최 소화하고, 고객과 기업의 니즈를 최대한 충족시 킬 수 있는 이러한 다양한 내용의 서비스를 가

〈그림 2-1〉 소디스 사업의 의의 및 특징

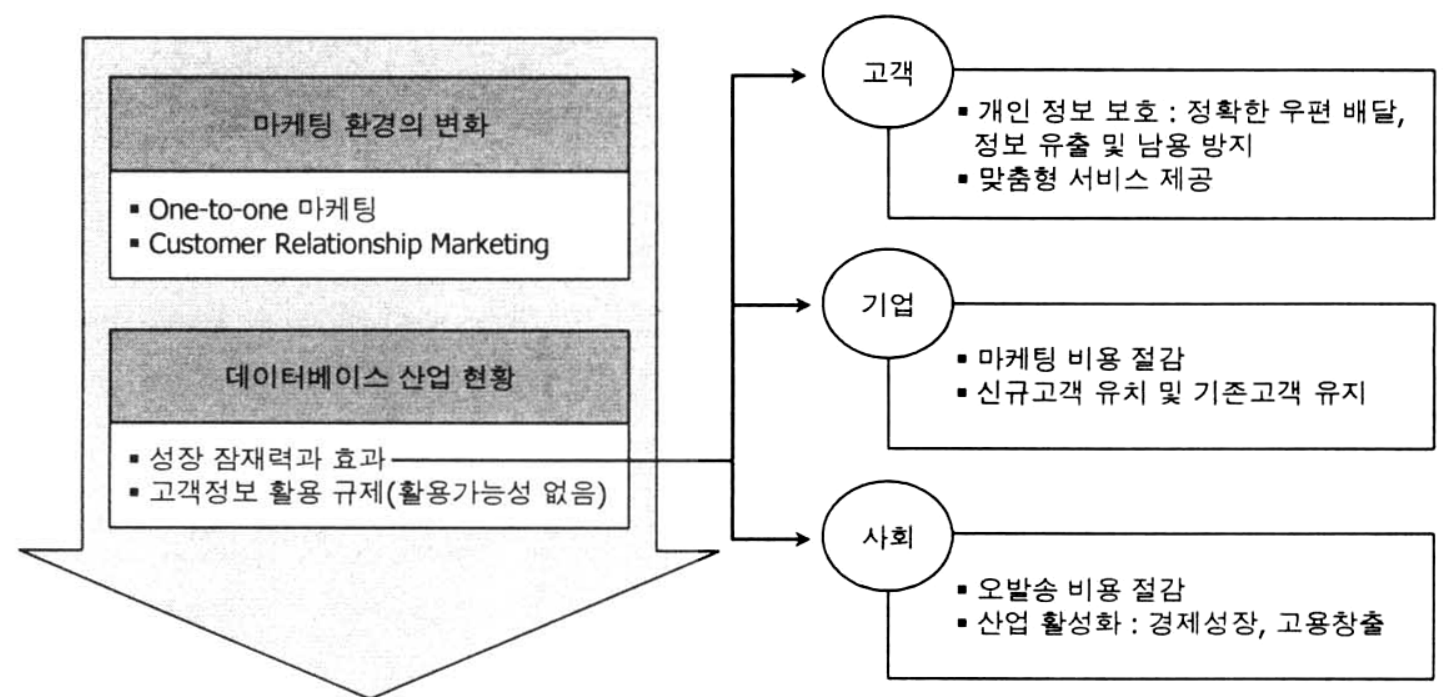

Win-Win-Win 모델

- 가구 정보 (vs. 개인 정보)

- $\mathrm{B} 2 \mathrm{~B}$ 와 $\mathrm{B} 2 \mathrm{C}$ 통합 모델 (고객정보 동의, 기업에게 마케팅)

- 마케팅 대행서비스 (정보 유출 방지) 
지고, 테이터베이스 마케팅 사업을 2004년 8월 13 일 출범하였다. $\mathrm{KT}$ 소디스 사업은 단지 신규 사업의 시도라는 의미를 넘어서, 사회적으로는 국내의 데이터베이스 마케팅 산업을 활성화하 고, 우편물 오배송 비용을 절감하며, 음성적으 로 거래되고 남용되고 있는 개인정보를 보호할 수 있다는 데 더 큰 의미가 있는 사업이었다. 또한, 각종 관련 산업의 발달과 그로 인한 경제 성장 및 신규 고용창출 효과에도 기여할 수 있 는 사업이었다. 기업 입장에서는 고객정보 갱신 및 표적고객 선정 서비스를 통하여 기존의 무 작위적 대량 마케팅에 비하여 훨씬 효율을 높 일 수 있게 되었다. 개인 측면에서 본다면, 소 디스 서비스의 출현은 음성적인 고객정보의 유 출 및 남용을 오히려 근절시키는 하나의 수단 이 되어 오히려 개인정보 유출의 위험에서 해 방될 수 있게 되었다. 이렇듯, 개인과 기업 그 리고 사회가 모두 win-win 할 수 있는 모델이 바로 $\mathrm{KT}$ 가 추구한 소디스 사업의 모습이라고 할 수 있다.

\section{4 시장조사를 통한 사업성 검증}

$\mathrm{KT}$ 는 소디스 사업 추진 전략을 구상하면서 실제로 사회에서 니즈가 존재하는가를 확인하 기 위해서 고객과 기업, 단체 등을 대상으로 시 장조사를 수행하였다. 시장조사에서는 $\mathrm{KT}$ 가 새 롭게 시작하는 데이터베이스 마케팅사업을 위 해 본인의 이름, 주소, 전화번호 정보 제공에 동의할 의향이 있는지를 조사하였다. 시장조사 결과 전체 응답고객 2,000 명 중 $64.4 \%$ 인 1,288 명의 고객이 동의하겠다는 의사를 나타냈 고, 그 중 $78.1 \%$ 의 고객이 실제 사업이 개시
되었을 때 동의를 실행할 의사가 있는 것으로 나타났다. 이러한 시장조사를 통해 실제 사업을 추진하면 단기간에 대규모 고객들의 동의를 얻 어내는 것이 쉽지는 않겠지만, 장기적으로 볼 때 충분히 많은 고객으로부터 동의를 이끌어 낼 수 있다는 것을 알 수 있었다

이렇게 많은 응답자들이 자신의 개인정보 활 용에 동의한 이유는 본인의 이름, 주소, 전화번 호는 이미 어느 정도 공개된 정보나 다름없다 고 생각하기 때문이다. 전화번호부에서도 이름 과 전화번호는 쉽게 찾을 수 있고, 주소 또한 어느 정도까지는 알아낼 수 있는 상황에서 $\mathrm{KT}$ 가 소디스라는 사업을 출범하며, 본인의 정보에 대한 활용에 동의하면 정보의 활용실적에 따라 발생되는 수익의 일부를 고객에게 돌려준다는 것이 상당한 호응을 얻을 수 있었다고 판단했 다. 이는 본인의 이름, 주소, 전화번호는 $64.4 \%$ 의 고객이 약간의 댓가를 받고 기꺼이 제공할 수 있을 만큼 민감한 정보는 아니라는 의미라 고 해석할 수 있었다.

한편, 고객정보를 사용하게 될 여러 기업에 대해서도 시장조사를 실시하였는데 이러한 조 사를 통해 많은 기업들이 소디스에서 제공하고 자 하는 서비스를 원하고 있다는 것을 확인할 수 있었다. 이는 우리나라 기업이 신규고객 확 보를 위해 필요한 마케팅 원료인 고객정보에 얼마나 굶주려 있었는지를 단적으로 보여주는 증거였다. 구체적으로 소디스 사업의 표적고객 서비스에 대해서는 면접대상 기업 중 보험, 할 인점, 요식업, 서적/출판, 자선단체 등이 가장 많은 관심을 보인 업종이었으며, 일정 비용을 지불하고 고객정보를 구매할 의향이 있다고 응 답한 기업이 전체의 $30 \%$ 나 되었다. 
고객정보 갱신 서비스에 대해서도 유사한 반 응이 나타났다. 고객정보갱신을 원하는 주요 기 업으로는 회원제 영업이나 마케팅을 하고 있는 업체 및 대량 $\mathrm{DM} \cdot \mathrm{TM}$ 업체들, 백화점, 카드 사, 보험사 및 동문회, 종친회 등을 들 수 있다. 이러한 기업체 및 단체를 대상으로 면접조사를 실시한 결과, $20 \%$ 에 해당하는 기업이 고객정보 에 대한 갱신서비스를 이용하겠다고 응답하였 다. 새로운 고객정보를 제공받는 것도 아니고, 자사가 보유하고 있는 정보를 업데이트하는 데 에도 그 정도의 비용을 지불하고자 한다는 것 은 그동안 맞는지 틀리는 지도 모르는 채 어쩔 수 없이 행하던 마케팅활동에 비용낭비가 심각 하였었다는 것을 공감하고 있었기 때문이라고 생각할 수 있다.

이와 같이 많은 기업들이 고객정보갱신서비스 에 비용을 지불하겠다고 응답한 것은, 고객정보 의 갱신을 통해 지속적으로 고객과의 접촉점을 유지하여 기존 고객의 이탈을 방지하고 로열티 를 증가시킬 수 있는 마케팅을 할 수 있기 때 문이다. 예를 들어, 500 만 명의 고객 $\mathrm{DB}$ 를 보 유하고 있는 한 자동차 회사의 경우. 5 년 전 소 형 자동차를 구매한 고객을 대상으로 중형 자 동차 판촉을 위해 테스트 메일을 발송한 결과 $70 \%$ 라는 엄청난 반송율을 기록한 바 있다. 반 송된 고객의 정보는 더 이상 존재하지 않는 고 객이나 마찬가지라고 할 수 있다. 이러한 기업 이 소디스의 고객정보갱신서비스를 이용하여 자사 고객의 정보를 업데이트하여 반송율을 $10 \%$ 대로 줄일 수 있다면 그것 자체로도 성공 적인 마케팅을 수행할 수 있는 것이다. 일반가 업 뿐만 아니라 동문회 등의 경우도 마찬가지 인데 약 5 만 명의 동문이 있는 대학의 경우 매
월 약 500 건의 반송우편이 발생한다면, 반송비 용은 건당 1,300 원으로 매월 약 65 만원, 매년 780 만원의 비용을 낭비하고 있는 것이다. 만약 주소갱신 서비스를 통하여 매월 반송 우편량을 100 건 이하로 줄일 수만 있다면, 이 동문회는 780 만원의 낭비 비용을 약 150 만원으로 줄일 수 있다.

이러한 다양한 시장조사를 통해 $\mathrm{KT}$ 는 소디 스 사업이 상당한 잠재력을 가지고 있음을 확 인할 수 있었다. 특히, 소디스 사업은 기업에게 는 비용의 절감혜택을, 정보제공자에게는 개인 적 정보의 유통에 대한 신뢰성 혜택을, $\mathrm{KT}$ 에게 는 새로운 수익을 창출할 수 있다는 점에서 사 적으로나 공적으로 반드시 추진해야 할 사업이 라는 확신을 갖게 되었다.

\section{III. 서비스 상품의 개발전략}

$\mathrm{KT}$ 는 소디스 사업이 상당한 잠재력을 가진 것을 확인하게 되자 사업을 본격적으로 추진하 게 되었으며 우선 소디스 사업의 비즈니스모델 을 설계하였다. 비즈니스 모델개발에 있어서는 특히. 데이터베이스 산업의 활성화를 막는 가장 큰 장애요인인 정보유출 우려에 대한 고객들의 불신을 제거하고, 고객들이 가치를 느낄 수 있 는 보상 방안을 마련하는 것이 핵심이라고 생 각하였다. 이러한 비즈니스 모델이 구체적으로 설계됨에 따라 국내 최초로 선도적으로 시작하 게 되는 $\mathrm{DB}$ 마케팅 인프라 사업을 가장 잘 표 현할 수 있는 브랜드를 개발하려는 노력을 기 울이기에 이르렀다. 


\section{1 프라이버시 보호 전략}

개인고객의 개인정보 활용에 대한 동의여부를 묻는 시장조사의 결과 생각보다 많은 사람들이 개인적 정보활용에 대해 동의를 하겠다고 했으 나, $30 \%$ 이상의 사람들은 아직 개인정보의 유 출에 대한 우려 때문에 쉽게 동의를 할 수 없 다고 하였다. 가장 큰 이유가 개인정보가 함부 로 유출되고 악용될 것 같다는 의견이었고, 그 로 인하여 이전보다 스팸 광고물이나 전화를 더 많이 받을 것 같다는 걱정 때문이었다. 이러 한 시장조사 결과는 고객정보와 관련해서 프라 이버시 보호가 얼마나 절실하게 필요한가를 반 증하는 것이기도 했다. 이러한 점에서 개인정보 유출에 대한 사람들의 우려를 효과적으로 처리 하지 못한다면 소다스 사업의 성공은 제한적일 수밖에 없다고 판단되어 $\mathrm{KT}$ 는 소디스 사업의 추진과정에서 고객정보 및 프라이버시 보호를 최우선 과제로 삼았다.

이를 위해 KT는 소디스 사업과 관련하여 다 음과 같은 프라이버시 보호전략을 추진하였다.

첫째, $\mathrm{KT}$ 는 소디스 사업에서 주민등록 번호 대신에 이름, 주소, 전화번호와 같이 고객이 민 감하다고 생각하지 않는 정보만을 활용하기로 하였다. 실제로 2003년 한국정보진흥원은 고객 은 주민등록번호, 신용카드번호, 예금계좌번호 등과 같이 유출되었을 때 직접적인 피해가 있 을만한 개인정보의 제공은 기피하지만, 이름. 주소, 전화번호, 소득 등의 개인정보는 비교적 부담 없이 정보를 제공하려 한다는 조사결과를 발포한 바 있다. 소디스 사업의 경우에도 이러 한 조사결과를 고려하여 수집하는 고객의 정보 는 민감하지 않은 정보로 한정하였고, 주민등록
번호 등의 민감한 정보에 대해서는 수집조차 하지 않는 방식을 채택하였다. 이는 개인정보의 유통 자체에 대해 거부감을 느낄 수 있는 고객 의 우려를 감소시키기 위해 $\mathrm{KT}$ 가 추진한 가장 차별적인 전략이라고 할 수 있다.

둘째, $\mathrm{KT}$ 는 고객들이 정보활용에 동의하는 과정에서 정보제공을 원치 않는 업체를 선택할 수 있도록 하였다. 예를 들어. 보험 마케팅의 대상이 되기 싫은 고객은 보험 업종에 대해서 는 정보제공을 원치 않는다는 의사를 표명할 수 있도록 하였다. 개인이 업종 전체 또는 개별 업체를 선택할 수 있도록 하여 고객의 본인정 보에 대한 통제력을 높였다.

셋째. $\mathrm{KT}$ 는 홈페이지를 통하여 본인의 정보 를 활용한 기업 리스트를 실시간으로 확인할 수 있는 모니터링 체계를 확립하였다. 언제 어 떤 기업이 어떠한 목적으로 어떤 정보를 활용 했는지를 구체적으로 확인할 수 있도록 함으로 써 정보활용의 투명성을 제고시키고, 고객의 불 안감을 해소할 수 있도록 하였다. 이와 더불어 정보를 활용한 기업의 리스트 확인과 동시에 정보활용을 통해 얻어진 본인의 수익 또한 함 께 확인할 수 있도록 하였다. 소디스는 이러한 방식을 통해 정보활용의 투명성 및 공정성을 보장하였다.

넷째, 소디스의 표적고객 서비스 및 고객정보 갱신 서비스 등 여러 서비스를 원하는 기업이 라고 누구나 사용할 수 없도록 하였다. KT는 기업 신용도 등의 엄격한 기준에 의한 심사를 바탕으로 고객이 신뢰할 수 있는 건전한 기업 들만이 소디스 서비스를 사용할 수 있도록 하 였고, 그렇게 선정된 기업과의 서비스 제휴 과 정에서도 고객정보의 유출 및 남용 등에 따른 
각종 사항에 대하여 엄격한 법적 책임을 규정 함으로써 기업이 함부로 고객정보를 유출하는 것을 방지하였다.

다섯째, 다른 제 3 자 기업에 제공하는 고객 정보 리스트 가운데 기업의 정보사용 및 마케 팅 활동의 건전성 여부 등을 감시할 수 있는 고객감시단을 일부 포함시켜, 기업의 고객정보 활용에 대해 지속적인 감시를 할 수 있도록 하 였다. 고객정보를 이용하는 기업들은 $\mathrm{KT}$ 를 통 해 제공받은 고객 리스트 중 어느 고객이 $\mathrm{KT}$ 의 숨은 감시단인지를 알 수 없기 때문에 자연 히 함부로 정보를 유출하거나 남용하는 행위를 할 수 없도록 하였다.

이상에서와 같이 $\mathrm{KT}$ 는 고객의 프라이버시 보호를 위해 다양한 전략을 마련하고 사업을 추진하였다. 이것은 현재 국내 어떤 기업이 고 객정보 유출 방지를 위해 취하고 있는 방법보 다 강력한 것이었는데 주민등록번호를 사용하 지 않는다는 한 가지 만으로도 고객정보 유출 에 따른 피해를 크게 줄이고자 하는 노력의 일 환이라고 할 수 있다. $\mathrm{KT}$ 는 고객정보의 활용 사업을 추진하면서도 고객정보 보호를 놓치지 않아야 한다는 생각을 전제하고 있는 것이다.

\section{2 고객에 대한 혜택 강화}

소디스 사업의 성공을 위해서는 정보를 제공 하고자 하는 개인들을 적극적으로 참여시키는 풀 전략이 중요하다. 개인의 입장에서는 개인정 보의 불법적인 유통을 줄일 수 있고. 주소변경 을 미처 하지 못한 기업으로부터 발송되는 자 신의 우편물이 오배송 되는 것을 막을 수 있는 등 눈에 보이지 않는 혜택을 제공할 수 있다.
개인고객은 소디스의 회원이 됨으로써. 주소가 바꿜 때마다 일일이 모든 기업이나 단체에 주 소변경을 하지 않아도 된다. 실수로 잊어버린 기업이 있더라도, 만약 그 기업이 $\mathrm{KT}$ 소디스의 고객정보 갱신 서비스를 사용한다면, 그 고객의 정보는 고객을 통해서가 아니라 소디스를 통해 서 갱신될 것이고, 우편물의 오배송에 대한 우 려 또한 자연히 사라지게 될 것이다. 실질적으 로 고객에게 느껴지는 경제적 혜택은 아니지만 최근 부각되고 있는 개인정보 유출의 심각성 등을 고려해 볼 때, 이는 더 중요한 가치로 인 정되는 혜택이라고 여겨질 수 있다.

고객은 소디스 서비스를 통하여 더 이상 스팸 광고가 아닌 본인에게 필요한 맞춤화된 정보를 제공받을 수 있을 것이다. 결혼을 했음에도 불 구하고 결혼정보 회사로부터 가입권유 전화를 받는 경우를 주변에서 자주 볼 수 있다. 또. 이 제 겨우 초등학생 자녀를 둔 부모에게 중고생 학습지 광고나. 아기용품 판매광고는 귀찮기만 한 스팸정보일 수밖에 없다. 이런 사례는 기업 이 효과적인 타겟 마케팅 수단을 갖추지 못하 여, 무작위적으로 마케팅 활동을 수행하기 때문 에 일어나는 결과라고 할 수 있다. 소디스는 이 러한 문제를 해결하기 위하여, 기업은 한 번의 홍보활동을 하더라도 정확한 고객에게, 고객은 광고전화 한 통을 받더라도 본인에게 필요한 내용을 받을 수 있도록 하는 서비스이다. 물론 마케팅이라는 것은 $100 \%$ 정확성을 보장할 수 는 없지만, 전략도 없고 대안도 없는 무작위성 대중 마케팅의 홍수에서 고객을 구출해 내고자 하는 것이 소디스가 고객에게 해줄 수 있는 또 하나의 혜택인 것이다.

그러나 이러한 혜택은 무형적이라는 점에서 
어떤 유형적인 혜택이 필요하다는 생각을 하게 되었다. $\mathrm{KT}$ 는 이 문제를 고민하다가 개인고객 의 정보를 고객의 자산으로 인정한다면, 고객 개인의 소유자산인 정보를 활용하여 발생한 수 익의 일부를 고객에게 돌려주어야 한다는 결론 을 내렸다. 이러한 결론을 실현하기 위해 $\mathrm{KT}$ 는 소디스의 개인정보 활용에 동의한 고객들에게 각 개인의 정보를 할용하여 발생한 매출의 $15 \%$ 를 고객에게 경제적 혜택으로 돌려주기로 결정하였고, 이를 $\mathrm{KT}$ 일반전화 요금의 감면형 태로 지급해주기로 하였다. 이는 세계 어느 누 구도 인정하지 않았던 고객의 이름, 주소, 전화 번호 정보를 고객 개인의 자산으로 인정하였다 는 데에 커다란 의의가 있다고 할 수 있다.

$\mathrm{KT}$ 는 이러한 개인적 혜택이외에 사회적 혜 택을 추가함으로써 사회발전에도 기여해야겠다 는 생각을 하게 되었다. 최근 여러 기업들에서 수익의 사회환원 활동에 많은 참여를 하고 있 는 추세인데 이를 반영하여 $\mathrm{KT}$ 도 소디스사업 이 고객의 참여를 통해 가능한 사업인 만큼 발 생된 매출의 $5 \%$ 를 사회에 환원하기로 결정하 였다. 그 일환으로 난치의 희귀병을 않고 있는 사회의 그늘진 곳에 있는 환자들을 위하여 매 년 환원사업을 벌일 것을 약속하였다. 본인의 정보활용으로 얻어진 수익의 일부가 주변의 어 려운 이웃을 돕는 데 쓰인다는 것만으로도 고 객은 뿌듯함을 느낄 수 있을 것이고, KT는 공 익을 수행하는 역할을 할 수 있는 것이었다. $\mathrm{KT}$ 소디스는 이렇듯 고객에 대한 직 · 간접적 인 혜택을 강화하여 보다 많은 고객의 동의를 유도하며 사업에 대한 개인고객의 만족도도 높 이고자 하였다.

\section{3 브랜드 개발 전략}

$\mathrm{KT}$ 는 국내 데이터베이스 마케팅 시장의 선 두주자로 소디스 사업을 출범하면서 이 사업의 사명감과 특성을 반영한 브랜드 개발에 착수하 였다. 신규 사업에의 진출이므로 $\mathrm{KT}$ 의 기업브 랜드로부터 신뢰감을 확보하면서 동시에 전문 성을 가지며 독자적 아이덴티티를 구축할 수 있는 브랜드를 개발하고자 하였다. 또한 성공적 으로 시장에 진입하여 선두 브랜드로서의 위상 을 정립하여 강력한 브랜드 이미지를 구축하고 자 하였으며, 커뮤니케이션의 효과 또한 극대화 할 수 있는 브랜드를 개발하고자 하였다.

우선, 이 사업을 성공적으로 출범하기 위해서 는 개인정보 수집과 활용에 대한 고객의 명시 적 동의를 수반해야 하므로 고객이 신뢰감과 친근함을 가질 수 있어서, 개인정보 수집과 활 용에 대한 동의를 이끌어낼 수 있는 브랜드여 야 했다. 또한, 일단 고객으로부터 정보제공과 활용에 대한 동의를 확보한 후 수집된 고객의 정보를 제 3 자 기업 등과의 업무제휴를 통해 정보갱신, 마케팅대행, 타겟 리스트 대행 등의 서비스를 제공해야 하므로 기업고객들에게는 데이터베이스 마케팅 분야에서의 전문성과 서 비스 품질에 대한 신뢰감을 느낄 수 있도록 하 는 브랜드여야 했다. 이를 위해 새로운 사업에 의 불안감을 극복하기 위해 $\mathrm{KT}$ 라는 기업브랜 드를 보조적으로 함께 사용할 수 있는 보증브 랜드가 중요하다고 판단했다.

이를 위해 국내에서 데이터베이스 마케팅과 관련된 여러 기업들의 브랜드를 비교 분석해 보았다. 대부분의 브랜드들은 정보관련 사업, $\mathrm{DB}$. 인포, DM, Mail 등의 단어를 포함하고 있 
는 한정적인 브랜드를 사용하고 있었다. KT는 브랜드 개발 과정에서 차후 사업 영역의 확장 과 단순한 $\mathrm{DB}$ 마케팅이 아닌 마케팅 전문 컨설 팅 사업으로서의 도약을 고려하여 광범위한 사 업을 포괄할 수 있는 브랜드를 개발하기 위해 $\mathrm{DB}$ 라는 한정적 단어에서 탈피하고자 하였다.

수십여 종류의 한글, 영문 브랜드 후보 안이 도출되었고, 브랜드 선호도 시장조사 등을 통하 여 발음용이성, 기억용이성, 전문성, 신뢰성 등 의 속성을 만족시키면서 고객에게 소구할 수 있는 브랜드로 브랜드 전문회사의 컨설팅을 참 고로 하여 "소디스(SODiS)를 선정하게 되었 다. SODiS란 “소금" 이라는 의미를 가진 단어 Sodium의 변형 신조어로서, 정보사회에서 소금 과 같이 없어서는 안 될 필수적인 존재가 되겠 다는 의미를 함축한다. 또한 발음용이성, 기억 용이성 및 전문적 이미지 연상 등 시장조사 결 과에서 타 후보 안에 비하여 월등히 높은 점수 를 획득하였고, 사업영역의 확장을 고려한 브랜
드의 확장가능성 측면에서도 확장가능성이 높 은 브랜드로 평가되었다. 소디스라는 브랜드가 바람직한 브랜드가 되기 위한 속성을 어떻게 충족시키는가를 살펴보면 다음 〈그림 3-1〉과 같다.

\section{IN. 소디스 사업의 마케팅 전략}

$\mathrm{KT}$ 의 소디스 사업팀은 소디스 사업의 사업 성이 확인되고, 비즈니스 모델과 브랜드를 결정 하였을 때 이제 난제는 대부분 해결되고 적극 적인 마케팅 활동만 전개하면 큰 문제가 없이 사업이 진행될 것이라고 생각했다. 그러나 막상 마케팅 활동을 전개하였을 때 소디스 사업을 적당히 알리고, 그 혜택을 설득하고, 정보제공 과 활용에 동의하도록 하는 것이 쉽지 않은 일 이라는 것을 절감하게 되었다. 소디스 사업팀은

〈그림 3-1〉 소디스 브랜드 개발

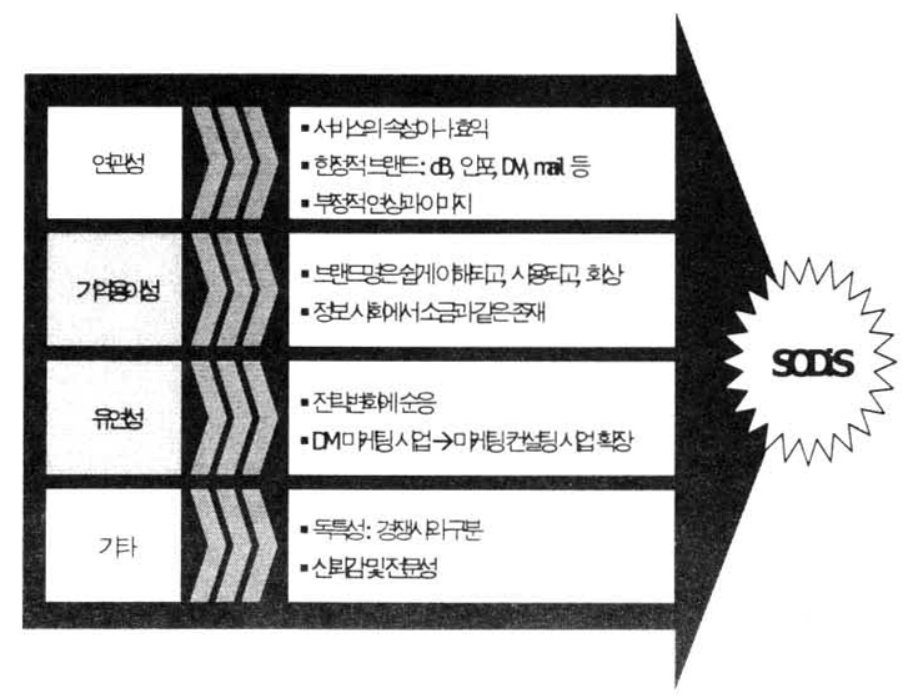


처음에 매스미디어 광고를 통해 소디스라는 브 랜드를 고객들에게 알리고자 노력하였으나 매 스광고로는 고객으로부터 동의를 획득하는 직 접적 반응을 얻어내는 것이 쉽지 않음을 경험 할 수 있었다. 이에 따라 소디스 사업팀은 커뮤 니케이션 매체의 성격과 사업의 특성을 고려하 여 마케팅 전략을 변화시킴으로써 많은 수의 고객동의를 획득할 수 있었다. 이러한 과정을 통해 점점 더 시장환경이 매스 마케팅이 아니 라 원투원(one-to-one) 마케팅으로 변화되어 가고, 매스미디어가 아니라 개인미디어로 변화 해 감을 확신할 수 있었다.

\section{1 초기의 마케팅 전략}

2004년 8월에 소디스 사업을 처음 런칭하는 시점에서 소디스 사업팀은 시장에 소디스라는
브랜드를 알리고 신뢰감을 형성하는 것을 목표 로 설정하고 마케팅 전랴을 수립하였다. 소디스 브랜드의 인지도를 단기간에 형성하기 위해서 는 역시 매스미디어를 활용해야 한다는 생각에 다음과 같은 마케팅활동을 전개하였다.

$\mathrm{KT}$ 는 소디스를 시장에 알리기 위해 '정보은 행'이라는 개념을 커뮤니케이션 전략에 도입하 여, 소디스에 이름, 주소, 전화번호를 "맡기다" 라는 카피의 광고를 집행하였다. 이것은 은행에 돈을 맡기듯 본인의 정보를 믿을 만한 곳에 맡 길 수 있는 서비스라는 점을 표현한 것으로, 앞 서 말했듯 고객의 정보를 자산으로 인정하며, 이러한 광고를 통해 고객의 신뢰감을 확보하고 자 하였다. 구체적으로 김정은, 조인성 등의 인 지도 높은 모델들을 활용하여 “나 00 으, 소디 스에 이름, 주소, 전화번호를 맡겼다"라는 카피 를 통해 호기심을 끌어내며. 동시에 나도 한번

〈그림 4-1〉KT 소디스 런칭 광고

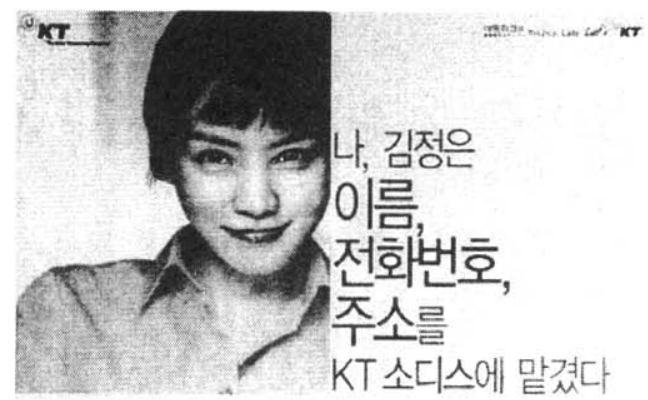

кTSOIS

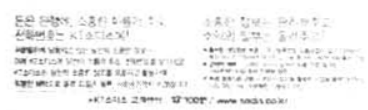

NF소낱 10대를 잡아라.

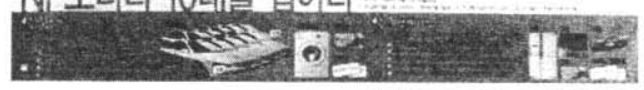

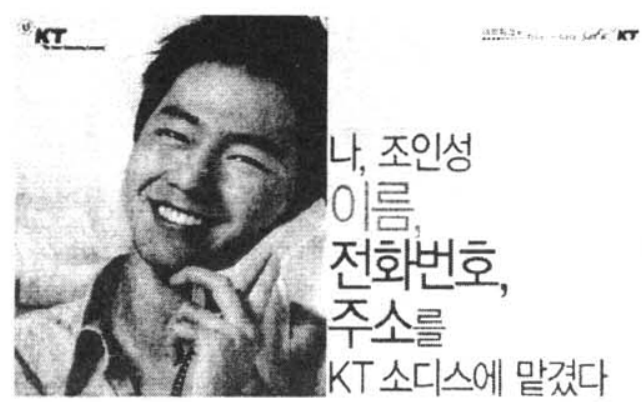

кTSOIS

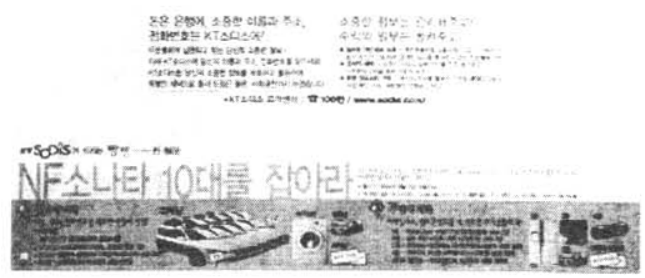


맡겨 볼까 하는 모방행동을 자극할 수 있는 광 고물을 제작하였다. 이러한 광고를 전달하는 주 된 광고매체는 신문 등의 인쇄매체였는데 주요 신문에 김정은, 조인성 등이 등장하는 광고물을 싣고, 최근 일간신문이나 스포츠신문에 비해 지 하철 무가지들이 효과가 커져 가는 추세를 고 려하여 주요 무가지에도 광고를 함으로써 비용 대비 최대의 효과를 얻고자 하였다.

또한 커뮤니케이션 효과를 높이기 위해 슬로 건에 대해서도 고심했는데 소디스 = 정보은행 이라는 개념의 커뮤니케이션 전랴과 함께 브랜 드의 슬로건을 "돈은 은행에, 내 정보는 소디 스에" 라는 모두에게 편안하게 인지되면서 동 시에 신뢰감을 심어줄 수 있는 슬로건을 사용 하였다. '소디스'라는 브랜드만으로 서비스의 성 격을 전혀 짐작할 수 없는 고객이나 기업들은 슬로건을 통해 신뢰감을 추구하고자 하는 정보 관련 서비스임을 다른 설명 없이도 인지할 수 있었다.

이와 함께 $\mathrm{KT}$ 가 국내에서 처음으로 데이터 베이스 마케팅 대상인 소디스를 시작한다는 메시지를 전달하는 라디오 광고를 실시하였는 데 아나운서 황현정을 기용함으로써 고객으로 부터 보다 더 신뢰성을 확보할 수 있도록 하 였다. 또한, 소디스의 서비스 내용에 대하여 간단히 설명한 만화를 $\mathrm{KT}$ 고객 전화요금 청구 서 소식지 내에 삽입함으로써 고객이 좀 더 쉽고 편하게 소디스에 대해 알 수 있는 기회 를 제공하였다.

브랜드를 알리는 것 이외에 소디스 사업 런칭 후 가장 시급한 것이 고객의 동의를 확보하는 것이었다. 동의고객이 없으면 사업 자체가 불투 명해지므로 자신의 개인정보 수집과 활용에 대
해 고객들의 동의를 받기 위한 여러 마케팅 활 동을 전개하였다. $\mathrm{KT}$ 는 런칭과 동시에 고객의 동의를 자극할 수 있는 대규모 경품 프로모션 행사를 기획하고, 이러한 프로모션 행사를 신 문, 인터넷, 라디오 광고 등 다양한 매스미디어 를 통해서 알렸고, 동시에, $\mathrm{KT}$ 고객에 대한 광 고 $\mathrm{DM}$ 을 발송하는 등 one-to-one 채널의 광고 도 시행하였다.

최근 매스광고를 하기 위한 비용은 실로 천문 학적인 자금이 소요되지만 그 효과에 대해서는 의문시되는 경우가 많다. KT 또한 프로모션 광 고를 집행하면서 그 사실을 절실히 깨달을 수 있었다. 사내 홍보용 방송물 제작을 위한 시장 조사의 일환으로 명동의 한복판에서 일반 시민 들을 대상으로 $\mathrm{KT}$ 소디스라는 브랜드의 인지 여부를 인터뷰한 결과, 거의 대부분의 고객들은 "들어본 적 없다" 고 응답했다. 브랜드 인지도 가 그만큼 낮다는 것은 광고를 보고 실제 소디 스의 정보활용에 동의하는 행동을 취한 고객은 훨씬 더 적을 것이라는 당연한 결과로 이어진 다. 이는 그 동안 매스광고에 쏟아 부었던 비용 의 효과성에 의심을 갖게 하는 결과라고 할 수 있다.

사업 런칭기에 대규모 프로모션을 시행하면서 소디스의 브랜드 인지도를 높이고, 정보활용에 대한 동의고객을 확보하고자 하였던 시도는 비 용대비 효과 측면에서는 실패한 것이나 다름없 었다. 실제로, 약 50 일의 기간동안 전체 응모자 수가 채 15 만 명에 못 미치는 매우 적은 규모 였고, 매스광고비의 일부를 순수한 브랜드 노출 에 소요된 비용이라 간주하더라도, 고객 1명이 동의하도록 하는 데 든 대략의 비용을 계산해 본다면 엄청난 금액이었다. 소디스는 이러한 사 
업 런칭 시점의 어려운 상황을 직접 경헙하면 서, 매스미디어 광고 효과에 대한 한계를 직접 느낄 수 있었고, 여러 다른 채널을 통한 마케팅 을 시행해 본 결과, 고객에 대한 커뮤니케이션 의 채널은 점차 one-to-one 방식으로 전개됨을 느낄 수 있었다.

\section{2 마케팅전략의 전환}

사업 런칭 초기의 매스 마케팅 전략에서 상당 한 어려움을 격었던 KT 소디스는 초반 프로모 션을 마무리하며 새로운 방식의 마케팅활동을 계획하기 위해 고민하였다. 엄청난 비용이 소모 되지만 그 효과는 터무니없이 낮은 인쇄광고와 비용만 낭비하는 노출기준의 온라인 배너광고 집행을 중단하고, 대신 고객에게 일 대 일로 접 촉할 수 있는 다양한 방식과 채널을 활용하기 위한 방안들을 모색한 결과, 다음과 같은 마케 팅 활동을 전개하였다.

첫 번째로 시도해 본 마케팅 활동이 휴대폰 을 통한 마케팅이었다. 사실 KT가 소디스라는 이름으로 본격적인 데이터베이스 마케팅 사업 에 착수하기 전부터 이동통신사들은 SMS 광 고를 하기 위하여 가입자들의 광고수신 동의 를 얻고 있었다. 그리하여 자사 이동통신 가입 자들에게 SMS를 통해 광고수신에 동의를 얻 고자 하는 다양한 이벤트를 진행하였는데 회 신율이 $10 \%$ 를 넘는 좋은 결과를 얻는 경우도 있었다.

이러한 결과에 자극받아 $\mathrm{KT}$ 는 소디스 동의 흭득을 위한 프로모션으로서 이동통신 3사의 고객들 중 SMS 광고수신에 동의하는 고객들만 을 대상으로 소디스에 대한 고객정보제공과 활
용에 동의를 구하는 SMS를 발송하였다. 이동 통신 3 사 고객 중 광고메세지 수신에 동의한 고객의 일부에게 경품행사 및 소디스를 홍보하 는 내용의 SMS를 발송하여, 정보활용 동의 희 신을 시도했으나 이동통신사에서 주장했던 것 과는 달리 회신율은 기대수준 이하였다. 반응율 은 $2 \%$ 를 밑도는 수준이었고, 해당 정보에 대한 신뢰성도 보장할 수 없었다. 더구나 $\mathrm{KT}$ 는 회신 을 받은 고객들에 대해서 동의의 신뢰성 확보 를 위해 또 다른 $\mathrm{TM}$ 을 해야 하는 번거로운 과 정이 필요했기 때문에 고객 일인당 동의비용이 증가했다. 이동통신사와 이러한 응답률의 차이 는 이동통신사에서는 SMS 발송대상자가 자사 고객이므로 고객에 대한 정보는 회신 번호만으 로도 확인할 수 있기 때문에 고객이 예·아니 오만을 선택하면 다른 정보를 직접 입력해야 하는 또 다른 번거로운 프로세스는 불필요했지 만, $\mathrm{KT}$ 의 경우에는 이동통신사의 고객의 휴대 폰 번호로 단지 동의만을 요청했던 것이기 때 문에, 고객명, 전화번호. 계약자명 등 너무 많은 정보를 $\mathrm{SMS}$ 를 통해 회신받거나 휴대폰으로 전 화를 해서 정보를 확인해야 했다. 당연히 프로 세스 중간에 고객 이탈율은 높아질 수밖에 없 었고, 이러한 점을 극복할 수 있는 효과적인 해 답을 찾는 것이 쉽지 않았다.

SMS 발송을 위해 구축한 전용회선 및 각종 설비 임대비용, 회신한 고객에 대한 재확인 $\mathrm{TM}$ 에 소요되는 비용 및 발송에 들어가는 직접 경비 등을 고려했을 때 고객 한 사람으로부터 동의를 얻는데 소요된 평균 비용은 매스광고를 통해 동의를 획득하는 비용과 비슷한 수준이었 다. 따라서 SMS 채널이 이동통신 업체에게는 유리한 마케팅 채널이었으나. KT에게는 상당한 
비용을 수반하는 수단이라는 결론을 얻었고, 이 에 따라 $\mathrm{KT}$ 는 테스트 마케팅 수준의 일부 고 객들에 대한 $\mathrm{SMS}$ 발송을 끝으로 $\mathrm{SMS}$ 채널의 활용은 중단하였다.

두 번째로 시행한 마케팅 활동은 기존의 온라 인 배너광고와는 약간 다른 방식의 온라인 광 고를 시행하는 것이었다. 일반적으로 활용되는 광고물에 노출된 고객 수에 따라 비용을 지불하 는 방식(CPM: cost per thousand/impression) 대신 고객의 직접적인 행동, 즉 클릭 혹은 회원 가입 등의 행동을 취한 경우에 대해서만 가격 을 책정하는 광고방식(CPA: cost per action) 을 활용하였다. 이러한 광고를 전문으로 대행하 는 업체들과 제휴하여, $\mathrm{KT}$ 는 영화 시사회 등의 소규모 프로모션을 진행했다. 프로모션이나 이 벤트 내용을 홍보하여 고객의 동의를 유도하는 방식으로 배너광고를 여러 사이트에 게재하고 해당 배너를 통해 유입된 고객에 대해서만 사 전에 약정한 광고단가를 지급하는 형태의 광고 였다. 이것은 기존의 $\mathrm{CPM}$ 방식의 온라인 배너 광고와 비교한다면, 효과의 보장 없이 소요되는 비용이 전혀 없다는 장점을 가지고 있었다. 고 객에게 제공되는 프로모션의 경품비용 역시 대 부분 광고 단가에 포함되어 있었기 때문에 $\mathrm{KT}$ 는 실제로 동의한 고객에 대해서만 비용을 지 급하면 되는 것이었다. 실제로 두 차례의 프로 모션을 시행하여 약 470 만 회 정도의 노출을 기록했고, 노출 대비 반응율은 $0.3 \%$ 에 불과한 것으로 집계되었다. 이렇게 낮은 반응율이 나타 난 것은 인기 사이트의 경우 노출도에 따라 광 고비를 책정하는 방식이 수익 창출을 위해서 횔씬 더 유리하고 광고수요가 많기 때문에 굵 이 클릭 수나 회원가입 실적에 따라 광고비를
받는 방식을 도입할 필요가 없기 때문이다. 따 라서 $\mathrm{CPA}$ 방식에 따라 광고를 하는 경우에는 중소규모의 비인기 사이트 쪽으로만 집중할 수 밖에 없으며, 결국 많은 사이트에 광고는 게재 하지만 얻을 수 있는 동의고객 숫자는 시장 규 모에 의해 한계가 있을 수밖에 없다. 비용 면에 서 본다면 굳이 낭비될 것은 없는 채널이지만 큰 효과를 거둘 수는 없다는 한계를 안고 있는 수단이라고 할 수 있다.

세 번째로 모바일, 온라인 등 기존의 마케팅 방식에서 나아가 오프라인 채널로의 확장을 시 도하였다. 오프라인 마케팅을 위해 제과점, 미 용실 등 소규모의 지역 업소들을 가맹점으로 보유하고 있는 고객관리 대행업체와의 제휴를 통하여, 업소를 방문하는 고객들을 대상으로 직 접 동의를 얻고자 하였다. 추첨을 통해 경품을 제공하는 이벤트에 응모할 수 있도록 하면서, 동시에 소디스의 정보활용 동의에 대한 내용을 소개하는 동의신청서를 각 가맹점에 비치해 놓 고 물건을 구매하거나 식사를 하기 위해 방문 한 고객을 대상으로 현장에서 동의를 유도하였 다. 해당 프로모션을 대행한 업체가 소규모 업 소들의 고객관리 솔루션을 입대, 유지보수 해주 고 있던 업체였으므로 지역 가맹점주들 간의 유대관계를 바탕으로, 현장에서 고객과 직접 접 촉을 하는 점주들의 협조를 쉽게 받을 수 있었 다. 점주들은 방문 고객들에게 적극적으로 소디 스롤 홍보하여 동의하도록 함으로써, 장기적으 로 자신의 보유고객에 대한 고객관리 등과 같 은 간접적 혜택을 얻고자 하였다. 또 다른 오프 라인 마케팅 방법으로는 메가박스, $\mathrm{CGV}$, 서울 랜드 등 유동고객이 많은 장소에 직접 동의 신 청서를 받을 수 있는 홍보부스를 설치하고, 고 
객의 동의를 유도하는 행사를 진행하였다. 초대 형 멀티플렉스 극장과 놀이공원에서 행사가 진 행되고, 또 $\mathrm{KT}$ 에서 새롭게 시행하는 사업이라 는 점이 고객들로 하여금 행사에 대한 신뢰감 을 다소 높여주는 장점은 있었으나, 유동고객이 많은 만큼 상당히 번잡한 현장에서 고객이 직 접 기재한 개인정보라서 그 정보의 정확성을 $100 \%$ 신뢰하기 어려운 단점이 있었다.

오프라인 마케팅은 온라인 마케팅과 달리 프 로모션 행사 실시에 상당히 큰 인력이 소요되 고, 시간도 오래 걸린다는 단점이 있다. 실제로 소규모의 지역 업소를 이용한 마케팅의 경우 행사가 시작된 후 신청서를 배포하고, 점주를 교육시키기 위해 상당한 기간이 소요되었고, 실 제로 고객의 반응이 들어오는 것은 더 오랜 시 간이 걸릴 수밖에 없었다. 또한, 각 점포에 고 객이 동의신청서를 기재하더라도 실시간으로 해당 고객의 정보가 $\mathrm{KT}$ 로 전달되지 못했고, 수 거된 신청서에 기재된 정보를 전산에 입력하더 라도 현장에서 인증절차 없이 기재된 데이터라 서 오류가 상당히 발생할 수밖에 없다. 그러나 오프라인 마케팅 활동의 경우에는 온라인과는 달리 본인이 현장에서 직접 참여한 것이기 때 문에 소디스에 대한 인지도는 상대적으로 높은 편이었고, 그에 따른 민원 발생 또한 거의 없다 는 장점이 있었다. 본인이 회원가입을 하고도 그 사실을 기억하지 못하는 경우가 다반사인 온라인 채널과는 차별화된 오프라인 채널만의 장점이라 할 수 있지만, 오프라인을 통한 행사 는 소요되는 비용과 인력소모 등이 상대적으로 높았다.

$\mathrm{KT}$ 는 이렇게 다양한 오프라인 채널을 활용 하여 고객의 동의를 획득하고자 했으나, 영향력
있는 채널은 아니었던 것으로 집계되었다. 하지 만, 좀 더 신속하고 효과적인 방법으로 고객에 게 접근하여 반응을 얻어내기 위한 체계적이고 전략적인 프로세스에 대한 방안을 마련한다면, 충분히 가치 있는 채널로 발전할 수도 있다는 것은 알 수 있었다.

\section{3 본격적 마케팅전략}

소디스가 시행했던 대표적인 동의획득 프로그 램 중에서 온라인과 오프라인을 결합하여 호과 적으로 추진했던 활동은 한 유통사와의 제휴를 통한 프로모션할동이었다. 일정 기간동안 방문 구매고객을 대상으로 구매 영수증에 이벤트 응 모번호를 찍어서 발행해 주었고. 고객은 백화점 의 홈페이지에 직접 접속하여 이벤트에 응모하 면서 동시에 소디스의 정보 활용에 동의할 수 있도록 하는 방식이었다. 백화점은 행사의 경품 비용과 매장 내 홍보 및 쇼퐝 광고지를 통한 홍보 등의 각종 비용을 제공하였고, $\mathrm{KT}$ 는 행사 를 통해 확보된 고객동의에 대해 건별 협정가 를 지불하였다.

이렇게 진행된 온·오프라인 결합방식은 현장 에 설치된 광고물 및 영수증을 통해 소디스에 서 진행하는 행사에 대해 한 번 인지하도록 한 후, 다시 홈페이지에 고객이 스스로 접속하여 동의를 클릭하도록 하는 방식으로 일반적인 온 라인 프로모션에 비하여 브랜드 및 행사에 대 한 인지도가 더욱 높아지는 장점이 있었다. 또 한 유통사 홈페이지의 회원을 대상으로 진행한 행사였기 때문에. 허위 정보의 유입이 제거된다 는 장점도 있었다. 주민등록번호와 같은 민감한 개인 정보는 수집조차 하지 않는 소디스로서는 
해당 사이트의 회원들만 참여할 수 있어 고객 의 정확한 정보만 수집된다는 점만으로도 행사 의 충분한 장점을 얻을 수 있었다. 대부분의 기 업이 데이터베이스 마케팅을 위해 가장 선호하 는 타겟 고객군이 남성보다는 여성, 미혼보다는 기혼, 또한 마케팅 대상으로서의 가치가 높은 30 대 50대 초반의 주부들이 주요 고객층이 된 다는 점에서 타 채널에 비하여 상당히 실속 있 는 채널임에 틀립없다.

소디스는 이러한 채널의 장점과 특성을 잘 살 려 매우 성공적인 결과를 얻어낼 수 있었다. 마 케팅비용 또한 동의한 고객 수에 따라 지급되 는 방식이었기 때문에 $\mathrm{KT}$ 로서는 호과에 대한 보장이 없는 비용을 낭비할 필요가 없었다. 유 통사의 입장에서는 이 판촉행사를 통하여 자사 매장을 방문하는 고객들에게 경품 응모라는 혜 택으로 고객 로열티를 증대시킬 수 있었고, 구 매 영수증을 받는 데서 행사가 끝나는 게 아니 라 온라인 홈페이지에 로그인을 해야 했으므로 홈페이지 회원가입 수를 늘릴 수 있었다. 뿐만 아니라 회원가입은 되어 있지만 로그인 등의 추가적인 활동이 전혀 없던 고객의 경우에도 행사 응모를 위해 로그인을 하게 되며, 일부 고 객의 경우 변경된 정보를 직접 수정하기도 하 는 등 고객 데이터 확보 측면에서도 이러한 이 벤트는 상당히 효과가 있는 이벤트라는 결과를 얻었다.

또 다른 성공적 프로모션 활동은 2004년 12월 부터 2005년 2월까지 3 개월 간 1, 2차에 걸쳐 시행했던 온라인 경품이벤트였다. 프로모션 대 행사를 통해 획득된 동의에 대한 건별 수수로 지급 방식으로, 일정 규모 이상인 경우 추가 인 센티브를 지급하는 방식으로 행사를 진행하였
다. 따라서 대행사는 각 사이트에서의 충분한 노출을 확보하기 위해 스스로 노력할 것이고, $\mathrm{KT}$ 의 입장에서는 일정 수준 이상의 동의를 확 보할 수 있다는 점이 이 프로모션의 강점이라 고 할 수 있다. 각종 대형 포털 사이트와. 인터 넷 쇼핑몰 등을 중심으로, 배너광고 게재는 물 론이고 이메일을 통한 마케팅 등 최대한 많은 노출을 확보하기 위한 다양한 전랴ㅇㅡㅡ 구사하였 다. 또한 기존의 온라인 배너광고 형식을 벗어 나, 재미있고 새로운 광고방식을 도입하여 고객 의 주목을 얻고자 시도하였다. 새로운 방식의 온라인 광고를 도입하고자 하는 과정에서 고객 에게 혼란을 야기시킬 수도 있다는 각 사이트 들의 입장으로 인한 여러 어려움도 물론 겪었 다. 그러나 다양하게 광고를 추진한 결과 높은 효과가 나타났으며, 기존의 배너광고 방식과 비 교하였을 때 노출 빈도 대비 상당한 수준의 고 객 동의를 확보하는 데 성공하였다.

이러한 온라인 이벤트는 총 1,2 차로 구분하 여 시행하였으며 고개이 쉽게 참여할 수 있으 면서도 관심을 가질 수 있을만한 간단한 게임 형태로 구성하였다. 일반적으로 고객이 선호하 는 여러 경품 이외에도 휴대폰벨소리 등 참여 만 하면 무조건 받을 수 있는 저가의 경품도 함께 마련하여 참여율을 높일 수 있었다. 또, 실적별 인센티브의 적절한 도입으로 대행업체 는 시작부터 끝까지 많은 고객의 동의를 확보 하고자 하는 KT의 목표에 부합하여 성실한 업 무를 수행하였고, 기존의 온라인 프로모션에서 는 볼 수 없었던 매우 성공적인 성과를 이루어 낼 수 있었다. 
〈그림 4-2〉 고객 동의 확보를 위한 소디스 마케팅 전략의 변화

\begin{tabular}{|c|l|}
\hline & \multicolumn{1}{|c|}{ 초기 전략 } \\
\hline 목표 & 인지도 제고, 신뢰성 확보, 고객 동의 획득 \\
\hline 커뮤니케이션 전략 & 정보 은행 \\
\hline 슬로건 & 돈은 은행에, 내 정보는 소디스에 \\
\hline 광고 & 신문 등 인쇄매체 중심, 노출기준 온라인 배너광고 등 \\
\hline DM & 요금고지서 등 \\
\hline 프로모션 & 대규모 경품이벤트 \\
\hline 성과 & 인지도 없음, 50 일, 15 만명 \\
\hline
\end{tabular}

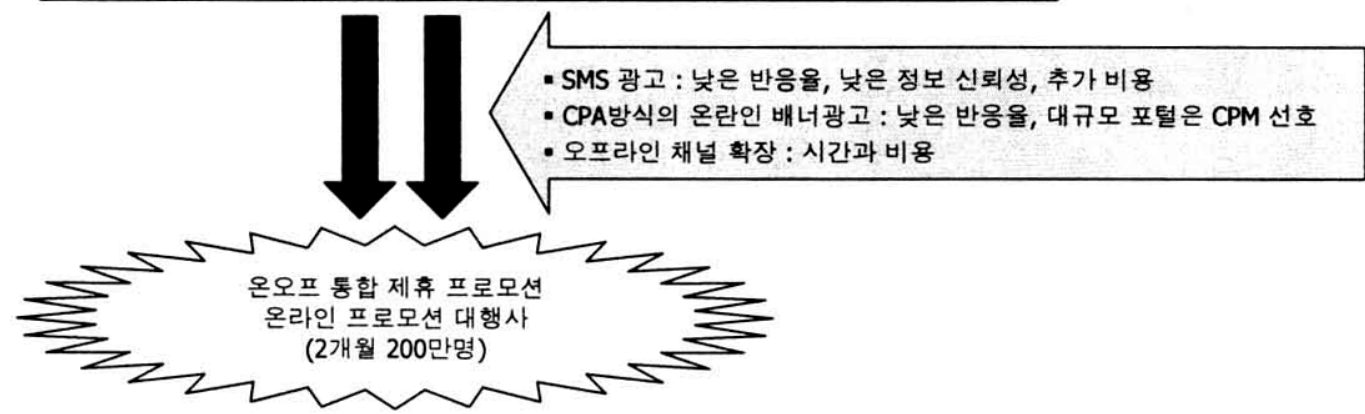

VI. 소디스 사업의 향후 과제

마케팅의 대상은 제품과 서비스 중심에서 경 험, 장소 정보, 아이디어 등과 같은 다양한 영 역으로 무한히 확대되고 있다. 특히 오늘날과 같은 정보화 사회에 있어서는 정보가 중요한 부가가치 창출 수단이기 때문에 마케팅 대상으 로서 정보의 중요성은 심대하다. 특히 고객정보 는 미래 글로벌 기업의 경쟁력을 결정하는 핵 심 자산이다. 많은 학계와 업계의 전문가는 정 보를 효율적, 효과적으로 수집, 관리, 활용 및 보호하는 기업이 미래의 시장을 지배하게 될 것이라는데 동의하고 있다.

고객의 정보를 이용한 데이터베이스 마케팅 활동은 우리나라에서는 아직 할성화되고 있지 못한 실정인데, 이는 불법적 개인정보의 유통과
이에 대한 고객의 막연한 두려움에 기인한다고 할 수 있다. 우리나라는 데이터베이스 마케팅을 전개하기에 비교적 좋은 인프라를 가지고 있는 편이다. 유선 및 이동통신서비스의 전국민적 보 급, 전국토를 커버하는 초고속 인터넷 서비스 및 신용카드의 발행과 활용 등과 같은 인프라에 있어서는 어느 나라에도 뒤지지 않는 경쟁력을 가지고 있지만 개인정보를 활용한 마케팅 활동 에 대한 심리적, 제도적, 사회적 장벽은 한 기업 이 극복하기에는 실로 너무 높다고 할 수 있다. $\mathrm{KT}$ 가 소디스 사업을 통하여 이러한 큰 장벽 을 처음 넘어서려고 했다는 데서 큰 의의가 있 다고 할 수 있다. 소디스 사업의 미래 성장을 예단하는 것은 성급한 감이 있지만 우리나라 데이터베이스마케팅의 초석을 다지는 인프라 구축을 위해 무거운 첫 걸음을 내디뎠다는 점 에서 마케팅 업계는 물론 학계에 있어서 가치 
있는 시도라고 할 수 있다. 이에 더하여 고객의 민감하지 않은 정보를 주로 활용하려고 했다는 고객지향적 관점의 마케팅 활동 전개, 이익금의 일부를 고객에게 환원하여 고객의 참여를 적극 유도하려고 한 점. 거의 불가능할 것으로 여겨 졌던 고객의 동의를 흭득하는 과정에서의 다양 한 마케팅 전략과 판매촉진 기법의 활용 및 기 업을 둘러싼 다양한 이해관계자 집단과 마케팅 환경에 대한 관리는 지금까지 시장에 존재하지 않았던 새로운 서비스를 도입하는 전랴을 연구 하고 개발하여야 하는 우리에게 큰 시사점을 던져주고 있다. KT가 소디스 사업을 통하여 개 인 정보를 활용하여 데이터베이스 마케팅을 할 수 있는 인프라를 구축하고 개인의 프라이버시 도 보호하고 기업의 경쟁력도 강화할 수 있는 길을 전인미답의 상황에서 처음 시도하여 국내 데이터베이스마케팅의 활성화에 기여하고 다른 기업들에게도 새로운 장을 열어주었다고 할 수 있다. 이러한 $\mathrm{KT}$ 소디스 사업은 새로운 마케팅 영역을 개척하고 고객, 기업 그리고 사회 모두 가 윈-윈할 수 있는 기회를 제공하였다는 점에 서 우리나라 마케팅의 경쟁력을 강화하기 위한 프런티어적 행보라고 할 수 있다.

〈사례 접수일: 2005. 09. 26〉

〈게재 확정일: 2005. 09. 26〉

\section{참고문헌}

김병도(2004), 코카콜라는 어떻게 산타에게 달 간 옷을 입혔는가?, 21세기 북스.

김병도 외(2004), "우리나라데이터베이스 마케 팅 관련 산업의 현황과 발전방안," 서울대 학교 경영연구소.

신종칠 외 역(2004), 신경제시대의 Kotler Marketing, A Framework for Marketing Management, 시그마프레스.

Yin, Robert K.(2000), Case Study Research, 3rd ed., Applied Social Research Methods Series, Sage Publications.

개인정보 보호, 활용 두 마리 토끼 잡자 上下, 중앙일보 2005. 05. 24 25.

개인정보보호기본법(안) 공청회, 열린우리당 이 은영 의원실 자료 중.

$\mathrm{KT}$ 소디스 홈페이지, http://www.sodis.co.kr. 데이터베이스 마케팅 활성화와 고객정보 보호를 위한 토론회, 연세대학교 IT정책전량연구소 자료. 


\title{
The First Step toward Database Marketing Industry in Korea; KT SODiS Case
}

\author{
Byung-Do Kim* \\ Seongtae Hong** \\ Jong Chil $\operatorname{Shin}^{* * *}$ \\ Myung Soo Kang*
}

\begin{abstract}
Most of the people in marketing area know that database marketing has been one of the most powerful marketing tools and thus database marketing industry grows bigger and bigger. For both effective database marketing and database marketing industry, personal data are the very essential resources. Unfortunately, in Korea, both database marketing and database marketing industry stays far behind compared to other countries because it is practically very hard to legally trade personal data for database marketing purpose. Instead Korea has a illegal spam problem which might be a natural consequency of strong restriction on personal data in the situation of huge demand for personal data. KT SODiS can be called the frontier of Korea's database marketing industry since it is the first legal business in this area. In the first 5 months, SODiS obtained 2 millions of legal customer consents which can be the strong base to help database marketing activities of other companies. This case shows marketing strategies of KT SODiS to establish infrastructure for Korea's database marketing industry and suggests some future tasks to further develop the industry.
\end{abstract}

Keywords: KT SODiS, database marketing, personal data protection, marketing strategy

\footnotetext{
* Professor, Seoul National University

** Associate Professor, Sangmyung University

*** Assistant Professor, Konkuk University

**** Assistant Professor, Hansung University
} 